\title{
Атанасова A.A.
}

\section{Трансформация ценностей социального предпринимателя в природоохранной деятельности}

Федеральный научно-исследовательский социологический центр Российской академии наук ул. Кржижановского, д. 24/35, корп. 5, г. Москва, 117218, Россия

atanasova.a.a@gmail.com

\section{Статья поступила 10 октября 2018 г.; Принята 12 февраля 2019 г.; \\ Опубликована 30 марта 2019 г.}

\begin{abstract}
Аннотация. Ценности определяют социальное поведение и могут служить разному направлению развития общества, его инволюции или эволюции. В зависимости от череды осознанных выборов, волевых решений, протяженных во времени, и трансформации ценностей происходит становление и развитие социальных предпринимателей как особой группы, трансформирующей общество. В данной статье рассматриваются теоретические основания для рассмотрения ценностей как эгоистических и альтруистических. Эгоистические ценности эволюционируют в альтруистические ценности с течением времени, привнося в жизнедеятельность личности (лидера, будущего социального предпринимателя) элементы социальной активности (участие в волонтерской деятельности, экологический активизм, социальная помощь другому). Социальные предприниматели в природоохранной деятельности своим организованным существованием сглаживают парадокс эколого-экономического противоречия, находя новые пути для функционирования зеленой экономики. Найти решение для по крайней мере двух социально-значимых интересов (благоприятной окружающей среды и экономической сферы) является весомым достижением феномена социального предпринимательства и личности каждого отдельно взятого социального предпринимателя. Говорить о нахождении равновесия в трех сегментах концепции устойчивого развития нужно постоянно, ведь именно в их сочетании кроется баланс мира. Место социального предпринимателя в достижении целей устойчивого развития в РФ может быть ключевым.
\end{abstract}

Ключевые слова: социальное предпринимательство; природоохранная деятельность; альтруистические ценности; эгоистические ценности; экологоэкономическое противоречие; устойчивое развитие; гражданское общество; сострадательное сознание.

Информащия для цитирования: Атанасова А.А. Трансформация ценностей социального предпринимателя в природоохранной деятельности // Научный результат. Социология и управление. 2019. Т. 5, N 1. С. 12-24 DOI: $10.18413 / 2408-9338-2019-5-1-0-2$

\section{Anna A. Atanasova}

Value transformation of the social entrepreneur in environmental activity

Federal Center for Theoretical and Applied Sociology of the Russian Academy of Sciences bld. 5, 24/35 Krzhizhanovsky St., Moscow, 117218, Russia 


\title{
atanasova.a.a@gmail.com \\ Received on October 10, 2018; Accepted on February 12, 2019;
}

Published March 30, 2019

\begin{abstract}
Values define social behavior and can serve different directions in the development of society, its involution or evolution. Depending on the sequence of deliberate choices and volitional decisions extended over time, the emergence and development of social entrepreneurs as a special group that transforms society is taking place. This article discusses the theoretical basis for considering values as egoistic and altruistic. Selfish values evolve into altruistic values over time, introducing into the life of the individual (leader, future social entrepreneur) elements of social activity (participation in volunteerism, environmental activism, social assistance). Social entrepreneurs in environmental activities smooth with their organized existence the paradox of eco-economic contradiction, finding new ways for the functioning of the green economy. Finding a solution for at least two socially important interests (favorable environmental and economic sphere) is a significant achievement of the phenomenon of social entrepreneurship and the personality of each individual social entrepreneur. It is always necessary to talk about finding an equilibrium in the three segments of the concept of sustainable development, because it is in their combination that the balance of the world is produced. The place of a social entrepreneur may be the key in achieving the goals of sustainable development in the Russian Federation.

Keywords: social entrepreneurship; nature protection activity; altruistic values; selfish values; eco-economic contradiction; sustainable development; civil society; compassionate consciousness.

Information for citation: Atanasova, A. A. (2019), "Value transformation of the social entrepreneur in environmental activity", Research Result. Sociology and management, 5 (1), 12-24, DOI: 10.18413/2408-9338-2019-5-1-0-2
\end{abstract}

«Если эволюция - это борьба за выживание, то почему она безжалостно не уничтожила альтруистов, которые, похоже, увеличивают перспективы выживания другого человека ценой своих собственных возможностей?», - Питер Сингер. Глава 1, Истоки альтруизма, С. 5.

Введение (Introduction). Одна из проблем, социальная и экологическая возрастание риска ухудшения здоровья и существования человека на планете. Социальные предприниматели в природоохранной деятельности выступают в роли взявших на себя часть коллективной ответственности за разрушение окружающей среды, то есть они выступают в роли приводящих хаос в порядок и восстанавливающих, регенерирующих окружающую среду. Но социальных предпринимателей в природоохранной деятельности мало, и их ценности следует изучить для того, чтобы взрастить и воспитать больше социальных предпринимателей в природоохранной деятельности, у которых преобладают альтруистические ценности и запал создавать общественно-полезный вклад. Решать проблему стоит через исследование практик социальных предпринимателей, обучение и воспитание новых социальных предпринимателей, социальную рекламу и пропаганду зеленых практик в ежедневной рутине жизни.

Методология и методы (Methodology and methods). Несмотря на то, что феномен 
социального предпринимательства уже узнаваем в нашей стране, все еще на карте этого понятия остались белые пятна. Существуют разные определения социального предпринимательства, а также разные подходы к его изучению, рассмотрим некоторые из них. Согласно одному из множества определений социального предпринимательства, данного Биллом Дрейтоном, основателем фонда «Ашока: инновации для общества», «социальное предпринимательство - это сообщества лидирующих социальных предпринимателей, работающих вместе» (Michelman, 2009). Это определение подчеркивает важность совместной работы социальных предпринимателей, то есть именно того процесса формирования сообществ социальных предпринимателей, который происходит в современной России.

Другое определение дала Ким Альтер (Alter, 2007: 12), исследователя социального предпринимательства: «социальное предпринимательство - это новый способ социальноэкономической деятельности, в котором соединяется социальное назначение организации с предпринимательским новаторством и достижением устойчивой самоокупаемости. В его основе лежит функционирование так называемых социальных предприятий предприятий, созданных с целью решения определенной социальной проблемы или проблем, действующих на основе инноваций, финансовой дисциплины и порядка ведения дел, принятого в частном секторе». Данное определение подчеркивает способ анализа социального предпринимательства через рассмотрение специфики самих социальных предприятий.

Еще одно определение, данное группой исследователей во главе с Шейкер А. Зара (Zahra, et al., 2009: 519-532) звучит так: «социальное предпринимательство включает в себя деятельность и процессы, предпринимаемые для открытия, определения и пользования возможностями для того, чтобы увеличить социальное богатство путем создания новых предприятий или управления существующими организациями в инновационной манере». Это определение показывает соци- альное предпринимательство сквозь призму социальных процессов.

«Социальное предпринимательство существует там, куда частный сектор не пойдет, и там, куда государство не может пойти. Социальное предпринимательство целесообразно рассматривать как механизм, решающий «проблемы государственного и частного сектора, которым в данный момент не уделяют внимания» (Haber, 2016: xi).

Немаловажным является и то, как исследователи определяют действующее лицо, социального предпринимателя. Бринкерхоф (Brinckerhoff, 2009: 37) считает, что «социальный предприниматель - это кто-то, кто берет на себя разумный риск от имени тех людей, кому служит его организация».

А Лидбитер (Leadbeater, 1997: 3) пишет, что «социальные предприниматели предприимчивые, инновационные и трансформирующие индивиды, которые также являются лидерами, рассказчиками историй, менеджерами людей, визионерамиоппортунистами и строителями альянсов. Они распознают социальную проблему и организуют, создают или управляют предприятием для того, чтобы произвести изменение».

В тематическом сборнике научных статей, посвященных анализу подходов к пониманию социального предпринимательства, изданном в 2009-ом году под редакцией Р. Циглера, утверждается, что «своей деятельностью социальные предприниматели напрямую влияют на государственную политику, разница в их опыте лишь в том, насколько власти в каждом случае готовы идти им навстречу. Одновременно почти все социальные предприниматели оценивают важность обучения для развития и распространения своего начинания» (Атанасова, 2015: 154-155).

Как видно из приведенных выше определений как феномена социального предпринимательства, так и самого социального предпринимателя исследователи оперируют разными аспектами этих явлений, но практически всегда сходятся в следующих составляющих: а. наличие социальной и/или экологической проблемы; б. бизнес-подход к ее 
решению; в. новаторство; г. роль сообществ в деятельности социального предприятия; д. социальный вклад; е. положение социальных предпринимателей как медиаторов решения проблем, которым государство и частный сектор не уделяют внимания.

«Все социальные движения начинаются с чувства недовольства существующим социальным устройством. Это чувство обусловлено двумя причинами: во-первых, объективными событиями и ситуациями, вовторых, критериями, эталонами, на основе которых люди их оценивают. Помимо общего чувства недовольства, люди должны обрести сознание несправедливости существующего положения вещей, его несоответствия нормам и ценностям общества. Они видят, что не принимаются никакие меры, чтобы изменить ситуацию; их вдохновляет представление о том, как должно быть. Чтобы это осуществить, надо создать какую-то организацию. Идеология придает значимость социальной проблеме, четко определяет ее с точки зрения понятий о добре и зле и предлагает руководство к действиям для исправления зла» (Смелзер, 1994).

Социальное предпринимательство как феномен не является социальным движением, однако социальные предприниматели, испытывая недовольство существующим социальным устройством в какой-то определенной сфере, выделяют социальную проблему, которую им бы хотелось решить, как и при функционировании движения в гражданском обществе. Создание вокруг социальных предпринимателей сообществ, их поддерживающих, помогает мягко трансформировать социальную среду, без нужды для революционных действий. Представим, что на всей территории страны пожар, социальные предприниматели и их предприятия, организовали бы огонь вокруг себя, являясь поглощающим его очагом нейтральности.

Социальный предприниматель оперирует без страха провала, под девизом: «А давай попробуем?», возможно, присутствует даже некая доля авантюризма, которая позволяет регулярно и дисциплинированно перешагивать через черту страха провала.
Сообщества социальных предпринимателей, харизма и сила социального предпринимателя, альтруистические ценности социального предпринимателя - рецепт успеха социального предприятия.

Ценностные ориентации социальных предпринимателей в природоохранной деятельности на данный момент являются неизученной областью исследования феномена социального предпринимательства. Целью данной статьи является определение понимания трансформационных процессов ценностных установок социальных предпринимателей в природоохранной деятельности.

Методологическая база исследования основана на фундаментальных общесоциологических представлениях о социальной сущности явлений и процессов, на новейших разработках относительно специфики трансформационных процессов (М.К. Горшков, П.М. Козырева), инноваций в социальной структуре современного российского общества (З.Т. Голенкова, М.Ф. Черныш, О.И. Шкаратан), на разделяемых научным сообществом принципах концепции устойчивого развития, на разработках сущности эколого-экономического противоречия (А.В. Мозговая), разработках относительно сущности социального предпринимательства (А.А. Московская), концепции ценностей и диспозиционной регуляции социального поведения личности (В.А. Ядов).

В совокупность методического обеспечения включены метод и техника сбора первичной социологической информации, инструментарий, разрабатываемый для реализации измерения соответствующих признаков выбранным методом и техникой, способ анализа и интерпретации полученных данных.

Поскольку феномен социального предпринимательства находится в стадии становления, и представителей совокупности социальных предпринимателей в целом и в природоохранной сфере в частности очень мало, методы количественного анализа не представляются адекватными в задуманном исследовании. Методология и методы качественной социологии как раз подходят для 
исследований формирующихся сообществ, отличающихся специфической субкультурой, своеобразной картиной мира, набором практик взаимодействия друг с другом и с социуMOM.

Научные результаты и дискуссия (Research results and discussion). Общॄие концепции определения ценностей. «Ценности - социально одобряемые и разделяемые большинством людей представления о том, что такое добро, справедливость, патриотизм, романтическая любовь, дружба и т.п. Ценности выражают то, как должен быть устроен мир и каким должен быть человек. Они не подвергаются сомнению, служат эталоном и идеалом для всех людей. Если верность является ценностью, то отступление от нее осуждается как предательство. Для описания того, на какие ценности ориентируются люди, в науке применяются ценностные ориентации. Ценности представляют собой разделяемые многими людьми убеждения относительно целей, к которым следует стремиться.

Ценностные ориентации описывают индивидуальные отношения или выбор конкретных ценностей в качестве нормы своего поведения. Если ценности выражают некоторые абсолютные нормы, цели, идеалы, которым следует все общество и которые оно свято чтит, то ценностные ориентации относительны и индивидуальны. Они проистекают от того, что индивид может свободно следовать идеалам, а может им не следовать. Ориентация на одни ценности и отвержение других называется ценностной ориентацией. Одни люди привержены ценностям коллективизма, а другие ценностям индивидуализма. Честь и достоинство семьи - одна из важнейших ценностей человеческого сообщества с древнейших времен. Проявляя заботу о семье, мужчина демонстрирует свою силу, храбрость, добродетельность и все то, что высоко оценивается окружающими. В качестве руководства к своему поведению он выбрал высокочтимые ценности. Они стали его культурной нормой, а психологическая установка на их соблюдение - ценностной ориентацией» (Кравченко, 2015: 340).

Ценности определяют социальное поведение, по Рокичу, «ценностные приоритеты индивидов могут выступать в роли целей, a также предпочитаемых способов их достижения, определяя поведенческие практики, распространенные в обществе» (Rokeach, 1973).

Ценности могут служить разному направлению развития общества, его инволюции или эволюции. В зависимости от череды осознанных выборов и волевых решений, протяженных во времени, происходит становление и развитие социальных предпринимателей как особой группы, трансформирующей общество.

Владимир Александрович Ядов разделял ценности на терминальные ценности или ценности-цели и инструментальные или ценности-средства. Если у Владимира Александровича Ядова ценности-цели достигаются посредством ценностей-средств и дополняют друг друга, то в классификации, предложенной автором данной статьи, эгоистические ценности противопоставлены альтруистическим во времени, трансформируясь из одного в другое.

В работе «Саморегуляция и прогнозирование социального поведения личности» очертил «приблизительный ценностноориентационный портрет инженеров СССР: «Семья и интересная работа - это главное в жизни если, конечно будет сохранен мир и не подведет здоровье. Общение с друзьями и любовь украшают мою жизнь. Разумеется, очень важно материальное благополучие, но оно - не самое главное в жизни. Что касается творчества, познания и достижений, достойных общественного признания, - это не всем удается, но было бы очень желательно. В чем я совершенно уверен, так это в том, что люди, живущие ради собственных удовольствий, ничего не стоят. Удовольствия приятны, но делать из этого цель существования недостойно» (Ядов, 2013: 74). Этот портрет вполне подходит для начинающего волонтера, который только встал на путь служения надындивидуальному. 
Важно разделение на эгоистические (направленные на благо себя) и альтруистические ценности (направленные на благо другого), которые определяют становление социального предпринимателя. Альтруистические - основополагающие, на них строится дальнейшая работа.

Эгоистические ценности эволюционируют в альтруистические ценности с течением времени, привнося в жизнедеятельность личности (лидера, будущего социального предпринимателя) элементы социальной активности (участие в волонтерской деятельности, экологический активизм, социальная помощь другому). Именно с течением времени и ростом осознанности происходит смена ценностных ориентаций у человека.

Не все социальные предприниматели движимы в начале деятельности альтруистическими ценностями, некоторые авторы считают (Моисеев, 2017), что для социальных предпринимателей первичным является материальная выгода и бизнессоставляющая процесса. И здесь не могу согласиться полностью, так как первичным с моей точки зрения является социальная миссия социального предприятия при условии устойчивой бизнес-модели функционирования дела. Согласно проведенному исследованию, даже те социальные предприниматели, кто начал строить бизнес, а лишь потом узнал, что они подпадают под определение социальных предпринимателей, признают важность социальной миссии и держаться своего вновь обретенного статуса и именования социальным предпринимателем, не отказываясь от того, что они строят настоящий бизнес.

Ценности СП в природоохранной деятельности. «Только благо может считаться ценностью ... Ценностные приоритеты всегда носят противоречивый характер» (Асонов, 2012: 14), благо не всегда легко достижимо. С чем и работают социальные предприниматели, склеивая разные заинтересованные стороны в рамках своего дела.

Ряд авторов, в том числе психолог, изучающий окружающую среду, Тациано Мил- фонт, из университета Виктории в Веллингтоне, Новая Зеландия, пишет о том (Hayley, 2018), что, с одной стороны, существуют люди, которые придерживается альтруистических ценностей, те, кто хочет достигнуть равенства в обществе, и они скорее склонны быть про-экологичными. С другой стороны, люди, которые сфокусированы на ценностях самосовершенствования и социальном доминировании склонны меньше волноваться о состоянии окружающей среды.

Ценности ведут к экологическинаправленному поведению, угроза или риск экологической катастрофы представляется объектом внутреннего внимания респондента, что ведет к действию, направленному на защиту окружающей среды. И «альтруистические ценности», и «ценности самосовершенствования» в подходе Тациано Милфонта и его коллег (Milfont et al., 2010: 27912813), (в понимании автора статьи: альтруистические ценности и эгоистические ценности) ведут к про-экологичному поведению.

Альтруистические и эгоистические ценности преобладают в человеке, заботящемся о природе, в зависимости от уровня развития общества. В развивающихся обществах про-экологичное поведение вызвано ценностями самосовершенствования или эгоистическими ценностями, в развитых обществах - ценностями альтруистическими или направленными на развитие сообщества.

Социальные предприниматели в природоохранной деятельности выбрали такую сферу профессиональной деятельности потому, что относятся к новой формирующейся группе заботящихся о природе людей, осознающих экологическую угрозу и риск экологической катастрофы. Они выступают в роли трансформирующих традиционное понимание бизнеса только ради прибыли, в бизнес с обязательной социальной и экологической направленностью. Понимая реалии ведения бизнеса в России, они не боятся коммуникации с властью и ежедневной деятельности предпринимателя в условиях неопределенности, получают позитивную обратную связь от сообществ, в которых функционируют. Группа социальных предприни- 
мателей в природоохранной деятельности пока не многочисленна, но растет, и можно в скором времени будет говорить о возникновении конкуренции между социальными предпринимателями в природоохранной деятельности. Есть даже такая концепция ««coopetition»: в условиях рыночной экономики приходится иногда соревноваться с коллегами по цеху, особенно, если ресурсов мало. Однако чаще всего им имеет смысл сотрудничать, поскольку это делает их проекты более эффективными, устойчивыми и конкурентоспособными» (Кикал, Лайонс, 2014: 22).

Личность социального предпринимателя, эколого-экономическое противоречие и устойчивое развитие. «Расширение возможностей управления собственным сознанием это путь утверждения в нем высших человеческих ценностей. Чтобы преодолеть глобальный кризис земной цивилизации, ведущий к деградации и гибели, надо преодолеть такие негативные свойства массового сознания, как неумное потребительство, агрессивность, крайний эгоизм». Главная, жизненно необходимая задача нашего времени, по словам Его Святейшества, Далай-Ламы, состоит в том, чтобы изменить наше сознание.

Высшие ценности реально существуют. Не у всех и не всегда, но у некоторых людей они выполняют важную функцию организации организма, поддержания его энергии, его воли, его целеустремленности.

«Напрашивается вопрос: откуда брать высшие ценности? Из религии? Необязательно. Человек может быть атеистом, но иметь высокий духовный потенциал. В глазах атеиста религия пытается приватизировать понятие духовности. Духовность - это приверженность высшим ценностям, но ее мы встречаем у многих атеистов. Многие атеисты были в высшей степени духовными людьми» (Дубровский, 2017).

Не могу судить о распределении социальных предпринимателей по религиозной принадлежности в России и, тем более, в мире, но то, что духовность в деятельности социальных предпринимателей на этапе эволюции ценностей в альтруистические при- сутствует. Наблюдая за жизнью нескольких социальных предпринимателей в социальных сетях, можно сделать вывод, что высшие ценности - они же альтруистические - на самом деле поддерживают энергию, волю и целеустремленность социального предпринимателя, выполняя важные функции организации организмов социальных предпринимателей. В цитируемой статье шла речь о нейронауке, возможно, социальные предприниматели открывают новые нейропути для всего «мозга общества»? А, если брать во внимание то, что природа является основой существования всех видов на планете, возможно, социальные предприниматели в природоохранной деятельности восстанавливают утраченные связи между погрязшим в потребительстве массовым сознанием и сознанием сострадательным и тяготеющим к помощи ближнему и планете?

Социальные предприниматели в природоохранной деятельности оперируют в условиях эколого-экономического противоречия, которое во многом и отражает столкновение сознания сострадательного и сознания потребительского. «Эколого-экономическое противоречие формируется вследствие несовпадения логики развития экономической сферы и интересов сохранения здоровой окружающей среды. Проявляется оно через конфликт таких базисных ценностей, как право граждан на благоприятную окружающую среду и охрану здоровья, и стремление отдельных лиц и групп населения к экономической выгоде любой ценой. Сущность противоречия состоит в столкновении по крайней мере двух социальнозначимых интересов, причем если субъект экономических интересов, как правило, очевиден, то носитель экологического интереса, будучи даже очевидным, зачастую неорганизован и, соответственно, не заявляет свою позицию» (Мозговая, 2004: 143-156).

Социальные предприниматели в природоохранной деятельности своим организованным существованием сглаживают парадокс эколого-экономического противоречия, находя новые пути для функционирования зеленой экономики. Найти решение для по 
крайней мере двух социально-значимых интересов (благоприятной окружающей среды и экономической сферы) является весомым достижением феномена социального предпринимательства и личности каждого отдельно взятого социального предпринимателя. Говорить о нахождении равновесия в трех сегментах концепции устойчивого развития нужно постоянно, ведь именно в их сочетании кроется баланс мира.

Эколого-экономическое противоречие может быть преодолено благодаря функцио- нированию социальных предпринимателей в природоохранной деятельности, ценности которых эволюционировали от эгоистических к альтруистическим.

Защита окружающей среды, а также инвестирование времени в помощь другим с дисциплинированностью и проявлением силы воли ведет социального предпринимателя в природоохранной деятельности к позитивной трансформации реальности и продвижению к решению социальной и/или экологической проблемы.

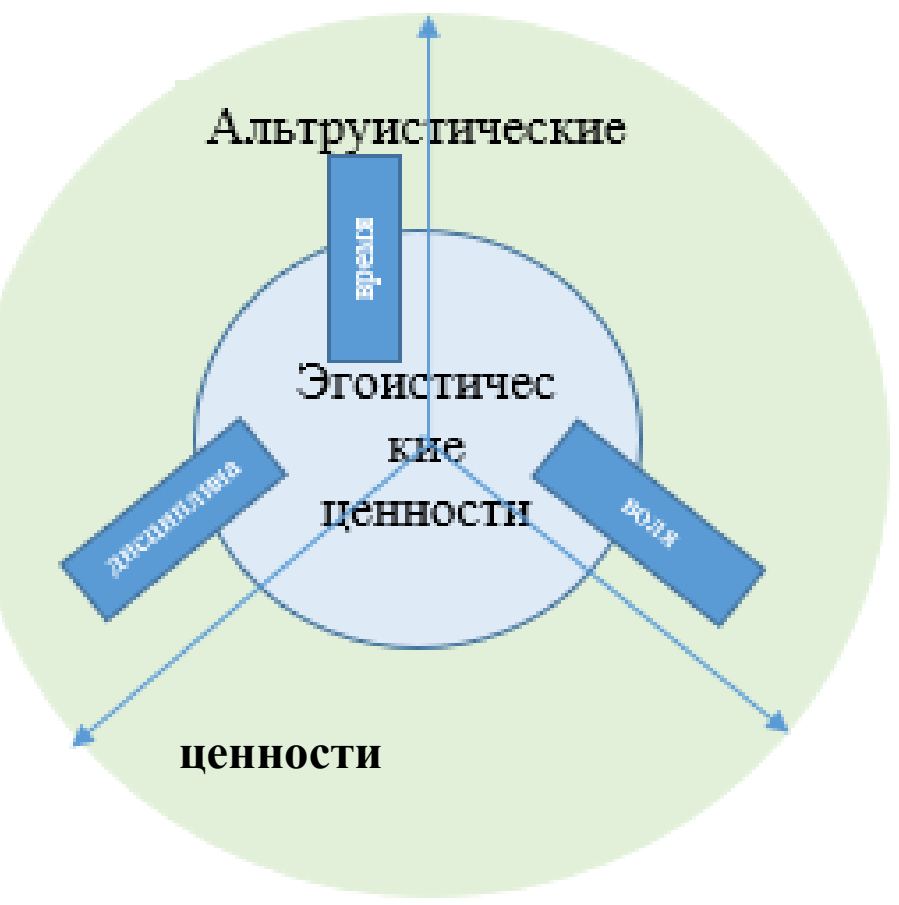

Рис. Эгоистические и альтруистические ценности социального предпринимателя

Fig. Egoistic and altruistic values of a social entrepreneur

Воля, время, дисциплина постоянное воспроизведение практик осознанных альтруистических действий в рамках работы социального предпринимателя в природоохранной деятельности. Трансформация социальных процессов происходит благодаря деятельности социальных предпринимателей в природоохранной деятельности и следованию ими целям устойчивого развития. Терпение играет также большую роль в успехе деятельности социальных предприятий.

«Люди, общности, их потребности, интересы, нормы, ценностные ориентации, традиции, родственные и социальные связи, - вот реальные двигатели социального и экономического развития, а вовсе не гиганты индустрии и мифические государственные интересы. Важнейшим социальным субъектом, от которого зависит направленность разрешения эколого-экономического противоречия 
являются гражданские движения и общественные организации, составляющие суть гражданского общества» (Мозговая, 2017: 103-115).

Трансформация ценностей социального предпринимателя в природоохранной деятельности как харизматичного лидера, фасилитатора, трансформирующего гражданское общество, достойный внимания феномен для дальнейшего изучения.

Из опрошенных 24-х социальных предпринимателей в природоохранной деятельности 1 респондент воздержался и назвал свои ценности, черты личности и понятия, связанные с гражданской позицией. Респондентам было предложено выбрать 3 наиболее важных с их точки зрения ценности в жизни человека, далее 3 наиболее важных в человеке черты личности, и - 3 наиболее важных понятия для них как социальных предпринимателей, связанных с их гражданской позицией.

K наиболее популярным ценностям социальных предпринимателей в природоохранной деятельности относятся: активная, деятельная жизнь (альтруистическая); общая хорошая обстановка в стране, в нашем обществе, сохранение мира между народами (как условие благополучия каждого) (альтруистическая); жизненная мудрость (зрелость суждений и здравый смысл, достигаемые жизненным опытом) (эгоистическая); здоровье (физическое и психическое здоровье) (эгоистическая).

K чертам личности социальных предпринимателей в природоохранной деятельности относятся: ответственность (чувство долга, умение держать слово) (альтруистическая); широта взглядов (умение понять чужую точку зрения, уважать иные вкусы, обычаи, привычки) (альтруистическая); эффективность в делах (трудолюбие, продуктивность в работе) (альтруистическая); жизнерадостность (чувство юмора) (альтруистическая); честность (правдивость, искренность) (альтруистическая).

Социальные предприниматели в природоохранной деятельности отметили в понятиях, связанных с гражданской позицией социальных предпринимателей такие понятия, как: свобода (эгоистическое); патриотизм (альтруистическое); демократия (эгоистическое/альтруистическое).

В инструментарии исследования предусматривался открытый вопрос, который дополнительно задавался социальным предпринимателям, чтобы прояснить их позиции и ценностные ориентации. Следующие группы ценностей были выявлены в ответах социальных предпринимателей:

- семья, дети, родители, семейные ценности (эгоистическая);

- финансовое обеспечение, финансовая стабильность, стабильность, материальное благополучие (эгоистическая);

- экологические и этические ценности; экология как гармония и чистота, в гигиеническом, социальном и ментальном плане; осознанность, гуманизм; право на здоровую, чистую окружающую среду, уменьшение вреда, наносимого окружающей среде, сохранение природных ресурсов, баланс в жизни всех людей, с точки зрения социального, экологического, биологического, при бережном отношении к окружающей среде (альтруистическая);

- обучаемость (общепредпринимательская задача); самообразование; развитие; саморазвитие (эгоистическая);

- миссия, то, что в личностной картине мира имеет смысл; право на самореализацию; то, что во мне созревает, необходимо вынести и сделать (внутренняя потребность), доносить до другого свою позицию, понимание; внесение вклада, возможность менять мир к лучшему (альтруистическая/эгоистическая);

- бизнес, который захватывает; человечески среагировал «сердечной мышцей»; баланс интересов бизнеса, природы и клиента, социальная справедливость, социально-ответственный бизнес; гармония устойчивое развитие (альтруистическая/эгоистическая);

- честность; искренность (альтруистическая); 
- внутренний судья, внутренняя работа, интуиция, душевный комфорт, независимая позиция, свой путь; согласие со своим внутренним миром, перенос внутренней позиции во внешнюю (эгоистическая);

- ответственность за предлагаемую технологию и производимый продукт; ответственность (альтруистическая);

ская);

- «не могу иначе» (альтруистиче-

- образность мышления; креатив-

ность (альтруистическая);

- любовь (альтруистическая).

Среди неповторяющихся, но все же важных ценностей социального предпринимателя в природоохранной деятельности можно назвать: смелость, принципиальность, настойчивость, доброту, сопереживание, свободу выбора, жизнь в согласии со своей совестью, жизнелюбие, окружение людьми «с большой буквы», локальную идентичность («чувствовать себя везде, как дома, вписываться в то место, где ты есть»), коллективную работу, коллективный консенсус в принятии решений, здоровье, взаимоуважение, порядочность, увлеченность. Высказывалось мнение, что не нужно «запечатывать социального предпринимателя в списки», что его душа шире и проявляется иначе, не по спискам.

Заключение (Conclusions). В рамках исследования изучены и типологизированы подходы к определению понятия и исследованию феномена социального предпринимательства; обоснована специфика социального предпринимательства в природоохранной деятельности на основе методологических положений концепции устойчивого развития и представления об эколого-экономическом противоречии; обоснован метод, сформирована совокупность респондентов и разработан инструментарий глубинного полуструктурированного интервью социальных предпринимателей в природоохранной деятельности; выявлена и проанализирована специфика ценностных ориентаций формирующейся группы социальных предпринима- телей в природоохранной деятельности; обоснованы факторы успешного становления и развития социального предпринимательства в природоохранной деятельности.

Основываясь на базовом принципе концепции устойчивого развития о единстве экономической, экологической, социальной сфер, пространство деятельности социальных предпринимателей в природоохранной деятельности предлагаю определять в границах допустимого состояния экологической сферы, приемлемого состояния экономической и справедливого состояния социальной сферы.

Информационно-аналитический анализ источников, включенное наблюдение внутри сообщества социальных предпринимателей привело к обоснованию специфической типологии ценностей: альтруистические и эгоистические ценности. Эгоистические ценности противопоставлены альтруистическим во времени, трансформируясь из одного в другое. Как методологическое основание такое разделение на альтруистические и эгоистические ценности позволяет проанализировать специфику становления и процесс функционирования социального предпринимателя, в том числе в природоохранной деятельности.

Инвестирование времени, самодисциплинированности и силы воли в защиту окружающей среды на благо общества ведет социального предпринимателя в природоохранной деятельности к позитивной трансформации реальности и продвижению к решению социальной или экологической проблемы на базе расширения пространства альтруистических ценностей и сужения пространства эгоистических ценностей.

В рамках исследования выявлен быстрый темп развития феномена социального предпринимательства, в том числе в природоохранной деятельности, при отсутствии четкого определения, что ведет к размыванию понятия. В связи с этим исследования существующих практик, специфики институционализации социальных предпринимателей, факторов, способ- 
ствующих и препятствующих становлению и развитию этой деятельности актуальны и значимы.

Анализ практики социального предпринимательства показывает, что для мягких перемен по защите окружающей среды действенны: личный пример, работа с сетями друзей и знакомых, создание государственных программ социальной рекламы в социальных сетях для формирования эталона ответственного гражданина, заботящегося об окружающей среде; поощрение малого и среднего предпринимательства, социального и экологического предпринимательства, развитие предпринимательских проектов по природоохранной деятельности на базе школ среднего и высшего образования, популяризация экодобровольчества, создание экологических юношеских кружков и групп (по выращиванию овощей и других культур совместно на базе школ, уборке территорий...), введение в образовательную программу профессионального обучения (в том числе с природоохранной направленностью), поддержка уже существующих НКО и лидеров мнений, ведущих просветительскую деятельность по защите окружающей среды, инвестирование в научные исследования поиска путей взаимодействия и гармоничной работы крупных корпораций и зеленых активистов, исследования зеленых городов и применения принципа осознанного потребления, повторного использования и переработки ресурсов.

Исследование выявило, что альтруистические ценности социальных предпринимателей в природоохранной деятельности определяют поведение их на рынке, доверие, нетворкинг, работу во имя общего блага, неувядающую уверенность в том, что все преграды можно преодолеть, терпение и баланс денежного и социального, денежного и экологического, веру в высшие ценности морали, их действия как будто «больше и тяжелее» по своей значимости, чем действия обычных предпринимателей, ведь за ними их добровольное желание взять на себя груз общественной ответственности за несправедливость.

Установка на открытие и развитие экологического предприятия, конечно, представляет собой краткосрочный риск для предпринимателя, ведет при этом, в долгосрочной перспективе к смене парадигмы войны и мира на парадигму мирного существования и предотвращения экологического коллапса.

В течение работы над данной темой автор стал свидетелем начинаний нескольких исследований ценностей социальных предпринимателей, что служит позитивным признаком актуальности и новизны темы статьи, а также способствует лучшему пониманию ценностей и ценностных ориентаций социальных предпринимателей в РФ.

\section{Список литературы}

Асонов Н.В. «Ценности» и «цели» в функционировании и эволюции сложной социальной системы. Материалы научного семинара. Вып. 2. М.: Научный эксперт, 2012.

Атанасова А.А. Рец. на кн.: «Введение в социальное предпринимательство: мнения, предпосылки, контексты» / Под ред. Р. Циглера // Социологические исследования. 2015. № 12 .

Дельфины капитализма. 10 историй о людях, которые сделали все не так и добились успеха / В. Моисеев, И. Просветов, Ю. Вишневецкая, А. Костюковский, Д. Соколов-Митрич, А. Рудницкая, О. Тимофеева, М. Ахмедова, А. Титова, Д. Виноградов. М.: Манн, Иванов и Фербер, 2017.

Кикал Дж., Лайонс Т. Социальное предпринимательство: миссия - сделать мир лучше. М.: Альпина Паблишер, 2014.

Кравченко А.И. Краткий социологический словарь. М.: Проспект, 2015.

Мозговая А.В., Комарова В.А. Социологическое обеспечение рисковой коммуникации // Риск: социологический анализ, коммуникация, региональное управление; Отв. ред. А.В. Мозговая. М.: Изд-во Института Социологии РАН, 2004. C. $143-156$.

Мозговая А.В. Эколого-экономическое противоречие: социальная сущность, субъекты, динамика // Ойкумена. Регионоведческие исследования. 2017. № 1 (40). С. 103-115. 
Смелзер Н. Социология. М.: Феникс, 1994.

Социальное предпринимательство в России и в мире / Отв. ред. А.А. Московская. М.: Издательский дом Высшей школы экономики, 2011.

Ядов В.А. Саморегуляция и прогнозирование социального поведения личности: Диспозиционная концепция. 2-е расш. изд. М.: ЦСПиМ, 2013.

Интервью, Давид Дубровский: Как можем мы, атеисты, не симпатизировать такой религии? // ВЗГЛЯД.РУ. 23 сентября 2017. URL:

https://m.vz.ru/society/2017/9/23/888186.html (дата обращения: 10.11.2017).

Alter S.K. Social Enterprise Typology. Virtue Ventures LLC, 2007. URL: http://rinovations.edublogs.org/files/2008/07/sety pology.pdf (дата обращения: 5.10.2018).

Bennet H. Have psychologists found a better way to persuade people to save the planet? // The Guardian. URL: https://www.theguardian.com/inequality/2017/nov /02/psychologists-better-way-persuade-people-tosave-planet-environment. (дата обращения: 7.10.2018).

Brinckerhoff P.C. Mission-based Management: Leading Your Not-for-Profit in the 21st Century. New Jersey: John Wiley \& Sons, Inc. Hoboken, 2009.

Haber J. The business of good: social entrepreneurship and the new bottom line. New York: Entrepreneur Media, Inc., 2016.

Leadbeater C. The rise of the social entrepreneur. London: Demos, 1997. URL: https://www.demos.co.uk/files/theriseofthesociale ntrepreneur.pdf (дата обращения: 7.10.2018).

Milfont T.L., Wagner C., Duckitt J. A Cross- Cultural Test of the Value-AttitudeBehavior Hierarchy // Journal of Applied Social Psychology. 2010. Vol. 40, № 11. Pp. 2791-2813. URL: $\quad$ https://doi.org/10.1111/j.15591816.2010.00681.x (дата обращения: 7.10.2018).

Michelman P. Interview with Bill Drayton, founder and CEO of Ashoka. Social Entrepreneurship - Its Past and Future // Harvard Business Review. $2009 . \quad$ № $5 . \quad$ URL: https://hbr.org/ideacast/2009/05/social-

entrepreneurship-its-pa.html (дата обращения: 7.10.2018).

Rokeach M. The Nature of Human Values. New York: The Free Press, 1973.
Zahra S., Gedajlovic E., Neubaum D., Shulman J. A typology of Social Entrepreneurs: Motives, Search Processes and Ethical Challenges // Journal of Business Venturing. 2009. № 24. Pp. 519-532.

\section{References}

Asonov, N. V. (2012), Values and goals of the functioning and evolution of a complex social system, Scientific seminar materials, Nauchniy Ekspert, Moscow, Russia. (In Russian).

Atanasova, A. A. (2015), "Review on a book «An introduction to social entrepreneurship: voices, preconditions, contexts»" (2009), in Ziegler, R. (ed.), Edward Elgar Publishing Limited, Cheltenham, UK, Edward Elgar Publishing, Inc., Northampton, MA, USA, Sociological studies, 12. (In Russian).

Moiseev, V., Prosvetov, I., Vishnevetskaya, Y., Kostyukovskiy, A., Sokolov-Mitrich, D., Rudnitskaya, A., Timofeeva, O., Akhmedova, M., Titova, A., Vinogradov, D. M. (2017), Capitalism dolphins. 10 stories about people who did everything wrong and succeeded, Mann, Ivanov, Ferber, Moscow, Russia. (In Russian).

Kickul, J. and Lyons, T. S. (2014), Understanding entrepreneurship. The relentless pursuit of mission in an everchanging world, Alpina Publisher, Moscow, Russia. (In Russian).

Kravchenko, A. I. (2015), Short sociological dictionary, Prospekt, Moscow, Russia. (In Russian).

Mozgovaya, A. V. and Komarova, V. A. (2004), "Sociological support of risk communication", in Mozgovaya, A. V. (ed.) Risk: sociological analysis, communication, regional management, IS RAS publishing house, Moscow, Russia. (In Russian).

Mozgovaya, A. V. (2017), "Ecological and economic contradiction: social essence, subjects, dynamics, Ojkumena. Regional research, 1 (40), 103-115. (In Russian).

Smelzer, N. (1994), Sociology, Feniks, Moscow, Russia. (In Russian).

Moskovskaya, A. A. (2011), Social Entrepreneurship in Russia and in the world, in Moskovskaya, A. A. (ed.), HSE publishing house, Moscow, Russia. (In Russian).

Yadov, V. A. (2013), Self-regulation and prediction of a person's social behavior: Dispositional concept, 2nd extended ed., Center of social forecasting and Marketing, Moscow, Russia. (In Russian). 
Interview, Dubrovskiy, D. (2017), "How can we, atheists, not like such a religion?", Vzglyad.ru, 23 September [Online], available at: https://m.vz.ru/society/2017/9/23/888186.html (Accessed 10 November 2018). (In Russian).

Alter, S. K. (2007), Social Enterprise Typology, Virtue Ventures LLC [Online], available at:

http://rinovations.edublogs.org/files/2008/07/sety pology.pdf (Accessed 5 October 2018).

Bennet, H. (2017), "Have psychologists found a better way to persuade people to save the planet?", The Guardian [Online], available at: https://www.theguardian.com/inequality/2017/nov /02/psychologists-better-way-persuade-people-tosave-planet-environment. (Accessed 7 October 2018).

Brinckerhoff, P. C. (2009), Mission-based Management: Leading Your Not-for-Profit in the 21 st Century, John Wiley \& Sons, Inc. Hoboken, New Jersey, USA.

Haber, J. (2016), The business of good: social entrepreneurship and the new bottom line, Entrepreneur Media, Inc., New York, USA.

Leadbeater, C. (1997), The rise of the social entrepreneur, Demos, London, UK [Online], available at: https://www.demos.co.uk/files/theriseofthesociale ntrepreneur.pdf (Accessed 7 October 2018).

Milfont, T. L., Wagner, C. and Duckitt, J. (2010), "A Cross- Cultural Test of the ValueAttitude-Behavior Hierarchy", Journal of Applied
Social Psychology, 40 (11), 2791-2813 [Online], available at: https://doi.org/10.1111/j.15591816.2010.00681.x (Accessed 7 October 2018).

Michelman, P. (2009), "Interview with Bill Drayton, founder and CEO of Ashoka. Social Entrepreneurship - Its Past and Future", Harvard Business Review, 9 (5) [Online], available at: https://hbr.org/ideacast/2009/05/social-

entrepreneurship-its-pa.html (Accessed 7 October 2018).

Rokeach, M. (1973), The Nature of Human Values, The Free Press, New York, USA.

Zahra, S., Gedajlovic, E., Neubaum, D. and Shulman, J. (2009), "A typology of Social Entrepreneurs: Motives, Search Processes and Ethical Challenges", Journal of Business Venturing, (24), 519-532.

Конфликты интересов: у авторов нет конфликта интересов для декларации.

Conflicts of Interest: the author has no conflict of interest to declare.

Атанасова Анна Атанасовна, аспирант 3 года обучения Федерального научноисследовательского социологического центра Российской академии наук.

Anna A. Atanasova, 3d-year PhD Student, Federal Center for Theoretical and Applied Sociology, Russian Academy of Sciences. 